\title{
Modeling of seasonal water balance for crop production in Bangladesh with implications for future projection
}

\author{
Mohammed R. Karim, Mamoru Ishikawa, Motoyoshi Ikeda \\ Graduate School of Environmental Science, Hokkaido University, Japan
}

\begin{abstract}
Regional or global climate change may have a significant effect on soil moisture and thereby affect plant growth. Water deficiency is considered to be one of the major climatic factors limiting crop production in Bangladesh, especially in the dry season. To better understand the response of crops to moisture variation, a quantitative analysis of major water balance components, namely, potential evapotranspiration (PET), actual evapotranspiration (AET), soil moisture storage (ST), water deficiency (WD), and water surplus (WS), was carried out using the Thornthwaite monthly water balance program. Analyses were carried out for three different seasons, incorporating interannual variability, in 12 major rice-growing districts of Bangladesh, which represented the northern, central, southern, and coastal zones. Hindcast monthly average surface air temperature and precipitation data were collected from the Bangladesh Meteorological Department (BMD) for the period 1986 to 2006. The analysis results suggested that the PET trend was the same at every station and that generally higher values were observed in the months of July and August. Khulna, a coastal station, had the highest annual average PET of $1369 \mathrm{~mm}$. The lowest annual AET of $1108 \mathrm{~mm}$ was estimated for Teknaf, while the second lowest value of AET was recorded in Dinajpur. The ST was found to be almost at field capacity from July to September, and the southern station of Chittagong had the highest average monthly ST. Future projection showed the northern part of Bangladesh would be less vulnerable
\end{abstract}

Correspondence: Mohammed Rezaul Karim, Graduate School of Environmental Science, Hokkaido University, N10 W5, Sapporo 060-0810, Japan. Tel. +81.80.32367395. E-mail: reza@ees.hokudai.ac.jp

Key words: deficit, evapotranspiration, moisture, season, surplus, water.

Acknowledgements: the authors thank the Bangladesh Meteorological Department for providing the climate data and the Bangladesh Bureau of Statistics for providing the data on rice production.

Funding: MRK received a scholarship and other financial support from MEXT, Japan.

Received for publication: 20 July 2011.

Accepted for publication: 27 December 2011.

(C) Copyright M.R. Karim et al., 2012

Licensee PAGEPress, Italy

Italian Journal of Agronomy 2012; 7:e21

doi:10.4081/ija.2012.e21

This article is distributed under the terms of the Creative Commons Attribution Noncommercial License (by-nc 3.0) which permits any noncommercial use, distribution, and reproduction in any medium, provided the original author(s) and source are credited. regarding ST. The maximum WD was found in Bogra, and the second highest value was found in Dinajpur. Estimation of the average WD of $178 \mathrm{~mm} \mathrm{yr}^{-1}$ in northern Bangladesh indicated that this region was subject to the greatest degree of WD and that winter is the most crucial season in determining water scarcity. The smallest value of WS was noted for the coastal station of Khulna. A significant positive relationship $(\mathrm{P}<0.05)$ between soil moisture and current rice yields proved the importance of surplus water conservation in the droughtprone zone of Bangladesh. To boost rice production and help cope with the consequences of climate change, integrated adaptation and mitigation measures should be adopted for agriculture.

\section{Introduction}

Bangladesh is the world's fourth largest producer of rice, and an area of about 11.53 million ha is used for the cultivation of rice. Three kinds of rice, viz. summer (aus), monsoon (aman), and winter (boro), are distributed throughout the country in response to climatic requirements; these account for $7.1 \%, 34.42 \%$, and $58.41 \%$ of total rice production, respectively (BBS, 2009). As the economy of Bangladesh is mainly agriculture-oriented, crop failure either by drought or by excess rainfall results in significant strain on the socioeconomic structure.

In Bangladesh, the year-to-year variation in crop yield is mainly a result of fluctuations in weather, the most important component of which is the amount of rainfall and its distribution during the life span of a crop (Murshid, 1987). The 1994 drought in eight northern districts of Bangladesh owing to deficient rainfall during the period June to September damaged crops in $20-30 \%$ of the planted area, and the yield was reduced by 25-30\% (Armstrong, 1996). Again, deficient rainfall from November to March affected the cultivation of winter vegetables, which reduced the demand for daily agricultural labor. The increase in the water deficit may be gradual but is sometimes dramatic, as it was in 1974-1979. The estimated yield reduction in Bangladesh, depending on the severity of drought, varied from 10-70\% (BARC, 1990). Rainfall is the single most important climatic parameter influencing agriculture in Bangladesh through the soil moisture reserve, since $36-40 \%$ of the cultivated land is non-irrigated. Rainfall needs to be utilized most efficiently by reducing harmful climatic effects and increasing beneficial outcomes, and this requires better planning of agricultural activities (Khan et al., 1991). Acute water shortage conditions combined with thermal stress adversely affected the productivity of wheat and, more severely, rice in northwest India even in the face of the positive effects of elevated $\mathrm{CO}_{2}$ (Lal et al., 1998). Quadir et al. (2004) reported that the northwestern area of Bangladesh experiences chronic water deficit and dry periods that vary from 3 to 6 months on average. In 1979, Bangladesh experienced a major drought, which resulted in disastrous crop failure. Karim et al., (1999) reported that even small soil moisture reserves in early February help the standing winter rice to a significant extent, while higher local rainfall would lead to severe 
floods in late August, resulting in significant rice loss. Thus, information about soil moisture storage in different areas and over different periods can be of immense help in determining the optimal water release from a reservoir in accordance with demand. When rainfall exceeds evapotranspiration, the soil moisture is recharged to field capacity, and any further rainfall causes surplus.

The percentage of filled grains is severely affected by moisture stress during the latter period of the growth of monsoon rice (Islam et al., 1992). Drought is a common incidence in Bangladesh, where almost every dryland farming crop is affected by water shortage. Substantial losses in crop production are caused by the shortage of available water even in a year with average rainfall (BBS, 1990). Any deviation from the required water supply hampers the physiological processes of rice notably. During the past 50 years, Bangladesh has experienced about 20 droughts. In 1982, drought caused a total loss amounting to about 53,000 tons of rice, as against the 36,000 tons lost by flood damage (Ramamasy et al., 2007). Floods cause lowered yields almost every year in some parts of Bangladesh. Although the effects of winter floods were not as significant, they still accounted for $10 \%$ of the total rice lost to floods during the period 1974-75 to 1998-99. Advanced general circulation models such as those from the Canadian Climate Center (CCC), the Geophysical Fluid Dynamics Laboratory (GFDL), and the United Kingdom Meteorological office (UKMO) estimated increases of 2-4, 46 , and $2-4^{\circ} \mathrm{C}$, respectively, in the winter season air temperature in Bangladesh for the doubling of $\mathrm{CO}_{2}$ (Mitchell et al., 1990). In the same study, a $1 \mathrm{~mm} \mathrm{~d}^{-1}$ decrease in precipitation (to $2 \mathrm{~mm} \mathrm{~d}^{-1}$ ) was predicted. Despite the uncertainties in the GCM predictions, their prognostications are still significant for climate change impact studies (Ghan, 1992).

To take proper crop growth initiatives, intensive study of the water balance is essential. Owing to less rainfall, the delayed onset of monsoon in some years in Bangladesh, and the limited, expensive facilities for irrigation, there is an urgent need for soil moisture measurements. Because of the consequences of climate changes, it is also necessary to have in-depth knowledge of soil moisture preservation, seasonal variation, the extent of water shortage, evapotranspiration demand, and ways to meet this demand, among other things. Assessment of monthly water balance parameters, which would involve estimation of water surplus and deficit, can help in addressing the above issues. When the combination of precipitation and soil moisture withdrawn from previous storage cannot meet the demand for potential evapotranspiration, a water deficit (WD) condition occurs. However, when the amount of water held in the soil at a particular time exceeds the storage capacity limit, a water surplus (WS) condition occurs, resulting in runoff. WD can be monitored either by keeping a continuous account of the moisture or the amount lost from the soil, so that no great moisture deficiency can develop in the soil to limit plant growth. The availability and management of soil water reserves will have an important influence on the attainment of potential yields in different climate change scenarios, especially when extreme events such as droughts occur more frequently and the annual soil and groundwater recharge decreases (Eitzinger et al., 2003). For judicious planning of long-term water resource management, an understanding of soil-water balance is useful, particularly with regard to evapotranspiration. The suitability of the crop-growing season in a region, in relation to WD or WS, can be estimated by such calculations. To improve the efficiency of rainwater use and gain a better understanding of the responses of crops to moisture variations in different seasons, a detailed quantitative analysis of the major water balance parameters would be of great use. In Bangladesh, few studies, especially those taking into account future climate changes, have been carried out to analyze the soil moisture status, which would have enormous effects on the crop yield. To satisfy the rising demand for rice in Bangladesh, production must be increased at a faster rate than that in the past. Measures should be adopted to over- come the current climatic constraints and the adverse effects of climate change so that higher production can be realized. In the current study, using the Thornthwaite water balance model (McCabe et al., 2007), seasonal and annual water balance components [potential evapotranspiration (PET), soil moisture storage (ST), actual evapotranspiration (AET), WD, and WS] are calculated for 12 selected stations in Bangladesh for the period 1986 to 2006.

On the basis of the climate change projection, the possible variation in the water balance components is also emphasized.

\section{Materials and methods}

\section{Study sites and data}

Four regions of Bangladesh, represented by 12 meteorological stations, were chosen for the study. Stations named Dinajpur, Rangpur, and Bogra represented the northern part; Faridpur, Tangail, and Dhaka represented the central part; Chittagong, Cox's Bazar, and Teknaf represented the southern part; Khulna, Patuakhali, and Bhola represented the coastal part (Figure 1)

Bangladesh has a humid, warm, tropical climate, and of the four prominent climatic seasons, winter (December to February) is relatively cooler and drier, with average temperatures ranging from a minimum of 7.2 to $12.8^{\circ} \mathrm{C}$ to a maximum of 23.9 to $31.1^{\circ} \mathrm{C}$. Pre-monsoon (March to May) is hot with an average maximum temperature of $36.7^{\circ} \mathrm{C}$, but in some places, the temperature occasionally rises up to $40.6^{\circ} \mathrm{C}$ or more. Monsoon (June to early October) is both hot and humid and brings heavy torrential rainfall throughout the season, and the mean monsoon temperatures are higher in the western districts than in the eastern districts. Post-monsoon (late October to November) is a short-lived season characterized by withdrawal of rainfall and gradual lowering of nighttime minimum temperature. The mean annual rainfall is about $2300 \mathrm{~mm}$, but there exists a wide spatial and temporal

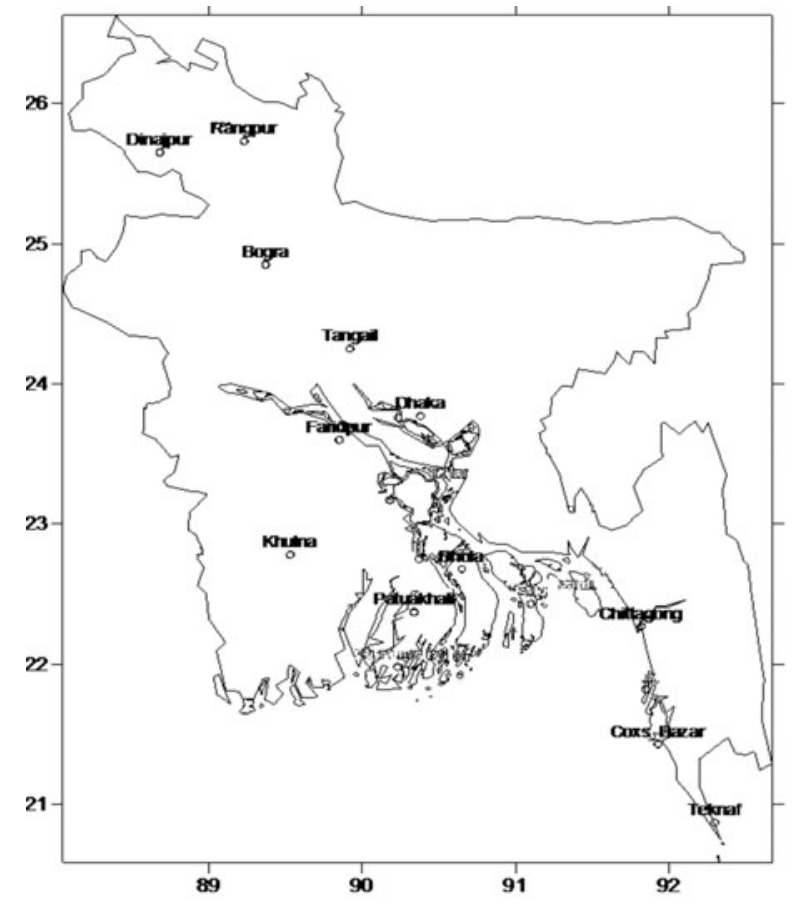

Figure 1. Map showing the study areas in Bangladesh. 
variation. Annual rainfall ranges from $1200 \mathrm{~mm}$ in the extreme west to over $5000 \mathrm{~mm}$ in the east and northeast (MPO, 1991). Generally, the eastern parts of the country experience higher rainfall than do the western parts.

Meteorological data were processed for use as input in the Thornthwaite water balance model. Monthly mean values of maximum temperature $\left({ }^{\circ} \mathrm{C}\right)$, minimum temperature $\left({ }^{\circ} \mathrm{C}\right)$, and total rainfall $(\mathrm{mm})$ were collected from the Bangladesh Meteorological Department (BMD) for the selected stations for the period January 1986 to December 2006. Mean monthly temperatures for the studied stations are shown in Table 1. The rainfall distribution is shown in Figure 2. Projected data on future climate were collected from the committed climate change experiment output for IPCC assessment report 4 in 2007. The output of several GCMs was used in the current study, depending on the resolution and availability of projection data. For example, for Dinajpur, Bogra, Dhaka, Chittagong, Khulna, and Patuakhali, projected climate data were sourced from the model output of the NOAA Geophysical Fluid Dynamics Laboratory CM2.1. For Rangpur and Bhola, the HadCM3 model output from the Hadley Centre for Climate Prediction, Met Office, UK, was used; for Faridpur and Teknaf, the CGCM 2.3.2a model output from the Meteorological Research Institute, Japan, was used; for Cox's Bazar, the E20 model output from the NASA Goddard Institute for Space Studies was used. Finally, the outputs of the climate model CGCM3.1 from the Canadian Centre for Climate Modelling and Analysis were used for the Tangail station.

Soil moisture storage (ST) refers to the amount of water held in the soil at any particular time. The amount of water in the soil depends on soil properties such as soil texture and organic matter content. Mean monthly ST values were calculated for the study seasons to investigate the impact of ST on the rice yield. The ST can be determined by calculating the input, output, and storage changes in water in a particular place for a particular time. The major input of water is from precipitation, and the major output is due to evapotranspiration. When the precipitation amount (that remaining after direct runoff) becomes higher than evapotranspiration, excess water enters the soil. This excess water is added to the previous month's reserve and is considered to be the ST. However, when precipitation becomes lower than evapotranspiration, part of the previously stored water is withdrawn (STW) to meet the demand for actual evapotranspiration. Thus, the current ST becomes lower as a result of the withdrawn moisture. The relation between the ST and the rice yield is determined by regression analysis, by calculating the correlation coefficient (r).

\section{Calculation of water balance parameters}

Monthly water balance components of the hydrologic cycle were computed using the Thornthwaite monthly water balance program. Inputs to the model were monthly mean temperature $\left({ }^{\circ} \mathrm{C}\right)$, monthly total precipitation (mm), and the latitude (degrees) of the location of interest; latitude was used to calculate the day length, which was needed for the estimation of potential evapotranspiration (PET).

\section{Precipitation}

For the estimation of monthly precipitation $\left(\mathrm{P}_{\text {rain }}\right)$ the threshold temperature for rainfall $\left(\mathrm{T}_{\text {rain }}\right)$ was specified as $3.3^{\circ} \mathrm{C}$. Since the average surface temperature in Bangladesh was above the threshold value, all the precipitation was considered to be $\mathrm{P}_{\text {rain }}$.

\section{Direct runoff}

Immediately after rainfall, some water enters stream channels or low-lying areas because of infiltration-excess flow; this is known as direct run off (DR0). The typical value of the direct runoff fraction (drofrac) is considered to be $5 \%$ of $\mathrm{P}_{\text {rain. }}$. DR0 is subtracted from $\mathrm{P}_{\text {rain }}$ to compute the amount of remaining precipitation, $\mathrm{P}_{\text {remain }}$, as in Eq. 1

$$
\mathrm{P}_{\text {remain }}=\mathrm{P}_{\text {rain }}-\left(\mathrm{P}_{\text {rain }} \times \text { drofrac }\right) \quad \text { Eq. } 1
$$

Table 1. Monthly temperature in Celsius degrees at different stations in Bangladesh during 1986-2006.

\begin{tabular}{lcccccccccccc} 
Stations & Jan & Feb & Mar & Apr & May & Jun & Jul & Aug & Sep & Oct & Nov & Dec \\
Dinajpur & 16.9 & 19.6 & 24 & 27.3 & 28.6 & 29.5 & 29.5 & 29.8 & 28.7 & 26 & 22.1 & 18.7 \\
Rangpur & 17.0 & 19.5 & 23.5 & 26.5 & 28.1 & 28.9 & 29.3 & 29.8 & 28.5 & 26.3 & 22.4 & 18.8 \\
\hline Bogra & 18.0 & 20.9 & 24.9 & 28.0 & 29.3 & 29.5 & 29.6 & 30.0 & 29.2 & 27.2 & 23.8 & 20.2 \\
Faridpur & 18.2 & 21.5 & 25.7 & 28.3 & 28.9 & 29.1 & 28.9 & 28.9 & 28.7 & 27.5 & 23.7 & 19.8 \\
\hline Tangail & 17.6 & 20.8 & 25 & 27.9 & 28.8 & 29 & 29.3 & 29.4 & 29.3 & 27.3 & 23.3 & 19.5 \\
Dhaka & 18.9 & 22.1 & 26.1 & 27.9 & 28.5 & 29.3 & 29.2 & 29.5 & 29.3 & 27.5 & 24.0 & 20.4 \\
\hline Chittagong & 20.3 & 22.4 & 25.6 & 27.3 & 28.4 & 28.8 & 28.9 & 29.0 & 29.0 & 28.1 & 24.9 & 21.8 \\
Cox'sBazar & 21.5 & 23.2 & 26.2 & 27.9 & 28.4 & 28.8 & 28.3 & 28.7 & 29.0 & 28.3 & 25.4 & 22.3 \\
\hline Teknaf & 11.9 & 22.6 & 25.6 & 27.3 & 28.1 & 28.5 & 28.1 & 28.2 & 28.3 & 28 & 25 & 22 \\
Khulna & 18.6 & 21.9 & 25.8 & 28.3 & 29.2 & 29.8 & 29.6 & 29.4 & 29.6 & 27.8 & 24.1 & 20.1 \\
\hline Patuakhali & 19.6 & 22.3 & 25.8 & 27.9 & 28.5 & 29.1 & 28.7 & 29.3 & 29.3 & 27.7 & 24.2 & 20.6 \\
Bhola & 18.9 & 21.5 & 25.5 & 27.7 & 28.2 & 28.9 & 28.6 & 29.0 & 29.0 & 27.7 & 23.9 & 20.5 \\
\hline
\end{tabular}




\section{Evapotranspiration and soil moisture storage}

Actual evapotranspiration (AET) is derived from PET, $\mathrm{P}_{\text {remain }}, \mathrm{ST}$, and STW. The PET value is estimated using the Hamon equation, as shown in Eq. 2 (Hamon, 1961), which is then used to calculate other parameters.

$$
\mathrm{ET}_{0}=13.97 \times \mathrm{d} \times \mathrm{D}^{2} \times \mathrm{Wt}
$$

where $\mathrm{ET}_{0}$ is the potential evapotranspiration in $\mathrm{mm} / \mathrm{month}, \mathrm{d}$ is the number of days in a month, $\mathrm{D}$ is the mean monthly hours of daylight in units of $12 \mathrm{~h}$, and Wt is a saturated water vapor density term, in grams per cubic meter, calculated as

$$
\mathrm{Wt}=\frac{4.95 x e^{0.62 x T}}{100}
$$

where $\mathrm{T}$ is the mean monthly temperature $\left({ }^{\circ} \mathrm{C}\right)$. When $\mathrm{P}_{\text {rain }}>$ PET, AET = PET, but when $\mathrm{P}_{\text {rain }}<$ PET, AET is calculated from Eq. 4 .

$$
\mathrm{AET}=\mathrm{P}_{\text {rain }}+\text { Soil moisture storage withdrawal (STW) Eq. } 4
$$

A soil-moisture storage capacity (STC) of $200 \mathrm{~mm} \mathrm{~m}^{-1}$ works well for most of the studied locations, which have silt loam soil. However, when AET $<$ PET, WD is calculated as PET - AET. Furthermore, when the ST becomes larger than the STC, the excess water becomes WS and is eventually available for runoff.

\section{Results and discussion}

\section{Potential evapotranspiration}

The monthly average potential evapotranspiration (PET) patterns were almost the same for all stations, but generally higher values were observed in the months of June and July and lower values were noted in December and January (Figure 3a). The increase in the PET from winter to monsoon was fairly rapid, while the PET subsequently decreased slowly in most cases. The monthly mean PET was the highest in Khulna (113 mm) and the lowest in Rangpur (107 mm) (Figure $3 \mathrm{~b})$. Khulna had the highest annual average PET of about $1369 \mathrm{~mm}$, and Rangpur had the lowest value of $1286 \mathrm{~mm}$ (Table 2). Chittagong, the easternmost station among the studied regions, showed an annual PET of $1345 \mathrm{~mm}$, whereas the northwestern station of Dinajpur had only $1308 \mathrm{~mm}$ (Table 2). The coastal region of Bangladesh had an annual PET of about $1345 \mathrm{~mm}$, which decreased to about $1316 \mathrm{~mm}$ in northern Bangladesh and to about $1338 \mathrm{~mm}$ in the central region (Table 2).

\section{Soil moisture storage}

Soil moisture storage was found to be almost at field capacity (200 $\mathrm{mm}$ ) during the period July to September at all the stations. Moisture reduced slightly by $76 \mathrm{~mm}$ to reach $87 \%$ of the field capacity in the postmonsoon period (October-November) and reached the lowest value of $40 \mathrm{~mm}$, or $45 \%$ of the field capacity, in winter (December-February) (Table 3). The ST began to decrease in November and reached the most negative value in April (Table 3), since the PET exceeded rainfall in
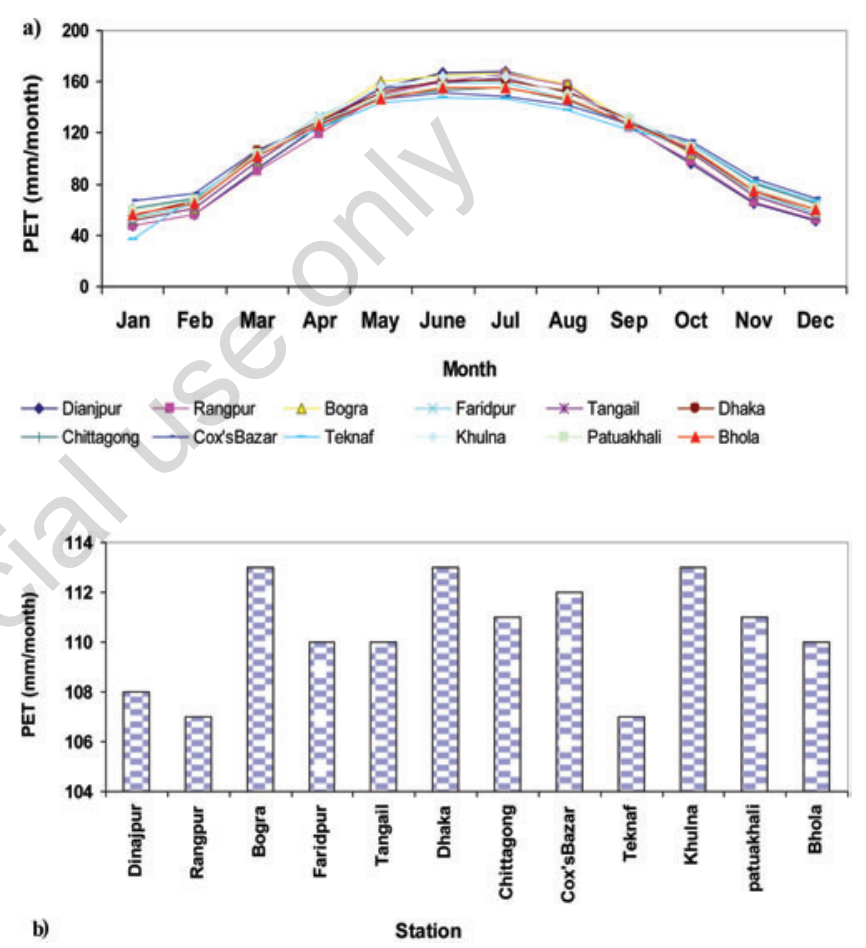

Figure 3. a) Station-wise mean monthly potential evapotranspiration; b) station-wise monthly average potential evapotranspira-

\begin{tabular}{|c|c|c|c|c|c|c|c|c|c|}
\hline Region & Station & $\begin{array}{c}\text { PET } \\
\text { Annual av. }\end{array}$ & $\begin{array}{c}\text { PET } \\
\text { Reg.av. }\end{array}$ & $\begin{array}{c}\text { AET } \\
\text { Annual av. }\end{array}$ & $\begin{array}{c}\text { AET } \\
\text { Reg. av. }\end{array}$ & $\begin{array}{c}\text { WD } \\
\text { Annual av. }\end{array}$ & $\begin{array}{c}\text { WD } \\
\text { Reg. av. }\end{array}$ & $\begin{array}{c}\text { WS } \\
\text { Annual av. }\end{array}$ & $\begin{array}{c}\text { WS } \\
\text { Reg. av }\end{array}$ \\
\hline Northern & $\begin{array}{l}\text { Dinajpur } \\
\text { Rangpur } \\
\text { Bogra }\end{array}$ & $\begin{array}{l}1308 \\
1286 \\
1355\end{array}$ & 1316 & $\begin{array}{l}1116 \\
1144 \\
1154\end{array}$ & 1138 & $\begin{array}{l}190 \\
142 \\
202\end{array}$ & 178 & $\begin{array}{c}905 \\
1104 \\
605\end{array}$ & 871 \\
\hline Central & $\begin{array}{l}\text { Faridpur } \\
\text { Tangail } \\
\text { Dhaka }\end{array}$ & $\begin{array}{l}1335 \\
1328 \\
1352 \\
\end{array}$ & 1338 & $\begin{array}{l}1193 \\
1196 \\
1224 \\
\end{array}$ & 1204 & $\begin{array}{l}141 \\
132 \\
128 \\
\end{array}$ & 134 & $\begin{array}{l}550 \\
609 \\
767 \\
\end{array}$ & 642 \\
\hline Southern & $\begin{array}{l}\text { Chittagong } \\
\text { Cox's Bazar } \\
\text { Teknaf }\end{array}$ & $\begin{array}{l}1345 \\
1355 \\
1292\end{array}$ & 1331 & $\begin{array}{l}1205 \\
1187 \\
1108\end{array}$ & 1166 & $\begin{array}{l}140 \\
168 \\
184\end{array}$ & 164 & $\begin{array}{l}1522 \\
2433 \\
2962\end{array}$ & 2306 \\
\hline Coastal & $\begin{array}{l}\text { Khulna } \\
\text { Patuakhali } \\
\text { Bhola }\end{array}$ & $\begin{array}{l}1369 \\
1342 \\
1323\end{array}$ & 1345 & $\begin{array}{l}1200 \\
1167 \\
1174\end{array}$ & 1180 & $\begin{array}{l}169 \\
175 \\
149\end{array}$ & 165 & $\begin{array}{c}535 \\
1261 \\
1007\end{array}$ & 934 \\
\hline
\end{tabular}
tion.

Table 2. Station and region wise annual average water parameters during 1986-2006.

PET, potential evapotranspiration; AET, actual evapotranspiration; WD, water deficit; WS, water surplus; Reg. av., regional average. 
these months at all of the stations. The southern stations, Chittagong and Cox's Bazar, had the highest monthly average moisture of $145 \mathrm{~mm}$ (Figure 4a). These stations received the highest rainfall, and hence, the soil moisture was the highest in the southern part during the monsoon and throughout the year (Figure 4b). Among the cropping seasons, moisture was the lowest in winter in all the regions (Figure 4b), and the season was favorable only for crops that could take up water from deep within the soil. During summer, the soil moisture was modest and the season was less suitable for agricultural crops than was the monsoon season. Rainfall was greater than loss through evapotranspiration in Cox's Bazar and Teknaf, and therefore, the ST was found to be almost at field capacity during the period June to September (Table 3). From the IPCC projections of climate change, it was found that all the studied regions in Bangladesh would suffer from water scarcity in future (Figure 4c). Compared to the annual soil moisture reserve of $1575 \mathrm{~mm}$ during the period 1986-2006, the average countrywide reduction was found to be $21 \%$ combined both for the year 2050 and 2100 (Table 4). Individually, the year 2100 would be more crucial for moisture loss. Stations located in the coastal belt would lose $47 \%$ of their soil moisture, whereas those in the central region would be less affected, losing only $21 \%$ of their moisture. Conversely, in terms of soil moisture, climate change might have some positive consequences for the northern part of Bangladesh, increasing the moisture by about $13 \%$. The pre- dicted scenario is found to be the reversed of current situation; i.e lowest moisture reserve only in northern Bangladesh.

\section{Actual evapotranspiration}

The AET depends mainly on the local vegetation type, precipitation pattern, and moisture storage in the soil for an individual station. The actual amount of evapotranspiration in the field is known as AET, which can be equal to or, in some cases, lesser than the PET. In Bangladesh, the annual average AET was the greatest in the central region and lower in the northern and southern regions (Figure 5); the highest average annual value (1204 mm) was found in the central part, and the lowest value (1138 mm) was found in the northern part (Table 2). Dhaka, a central station, had the highest average annual AET of around $1224 \mathrm{~mm}$, while Teknaf had the lowest annual AET of $1108 \mathrm{~mm}$ (Table 2). During the pre-monsoon season, the monthly mean AET ranged from 89 to $106 \mathrm{~mm}$ and the central region suffered from the highest water loss (Figure 5). In the monsoon season, the AET and PET values were very similar at all stations. During the post-monsoon season (OctoberNovember), the northern part had a monthly average AET of $80 \mathrm{~mm}$, while the southern belt had the highest monthly average of $97 \mathrm{~mm}$. In winter (December-February), the northern part had the lowest monthly AET value of $32 \mathrm{~mm}$, while the southern region had a monthly maximum AET value of $44 \mathrm{~mm}$ (Figure 5). With adequate moisture in the

Table 3. Monthly and annual average soil moisture in mm during 1986-2006.

\begin{tabular}{|c|c|c|c|c|c|c|c|c|c|c|c|c|c|c|c|}
\hline \multirow{4}{*}{$\begin{array}{l}\text { Region } \\
\text { Northern }\end{array}$} & Station & Jan & Feb & Mar & Apr & May & Jun & Jul & Aug & Sep & Oct & Nov & Dec & Annual av. & Reg.av. \\
\hline & Dinajpur & 83 & 64 & 39 & 37 & 96 & 168 & 193 & 190 & 200 & 177 & 128 & 99 & 1474 & \multirow[t]{3}{*}{1485} \\
\hline & Rangpur & 82 & 64 & 45 & 65 & 138 & 200 & 198 & 189 & 197 & 180 & 130 & 101 & 1589 & \\
\hline & Bogra & 76 & 58 & 35 & 35 & 79 & 154 & 187 & 185 & 195 & 175 & 121 & 92 & 1392 & \\
\hline \multirow[t]{3}{*}{ Central } & Faridpur & 85 & 70 & 55 & 58 & 111 & 177 & 197 & 194 & 192 & 179 & 139 & 106 & 1563 & \multirow[t]{3}{*}{1607} \\
\hline & Tangail & 86 & 72 & 55 & 74 & 145 & 178 & 191 & 189 & 200 & 182 & 137 & 107 & 1616 & \\
\hline & Dhaka & 86 & 65 & 53 & 79 & 143 & 182 & 199 & 195 & 200 & 186 & 144 & 109 & 1641 & \\
\hline \multirow[t]{3}{*}{ Southern } & Chittagong & 83 & 68 & 59 & 84 & 154 & 191 & 200 & 192 & 197 & 188 & 153 & 113 & 1683 & \multirow[t]{3}{*}{1657} \\
\hline & Cox'sBazar & 84 & 63 & 49 & 55 & 151 & 200 & 200 & 200 & 200 & 192 & 159 & 118 & 1672 & \\
\hline & Teknaf & 94 & 71 & 41 & 28 & 120 & 200 & 200 & 200 & 200 & 189 & 162 & 114 & 1617 & \\
\hline \multirow[t]{3}{*}{ Coastal } & Khulna & 81 & 72 & 62 & 41 & 73 & 145 & 191 & 191 & 190 & 177 & 141 & 102 & 1468 & \multirow[t]{3}{*}{1548} \\
\hline & Patuakhali & 79 & 63 & 49 & 66 & 121 & 183 & 191 & 191 & 194 & 182 & 145 & 104 & 1565 & \\
\hline & Bhola & 82 & 66 & 58 & 64 & 127 & 189 & 200 & 200 & 198 & 178 & 142 & 104 & 1610 & \\
\hline
\end{tabular}

Reg. av., regional average.

Table 4. Soil moisture change in percentage at different stations in Bangladesh for 2050 and 2100.

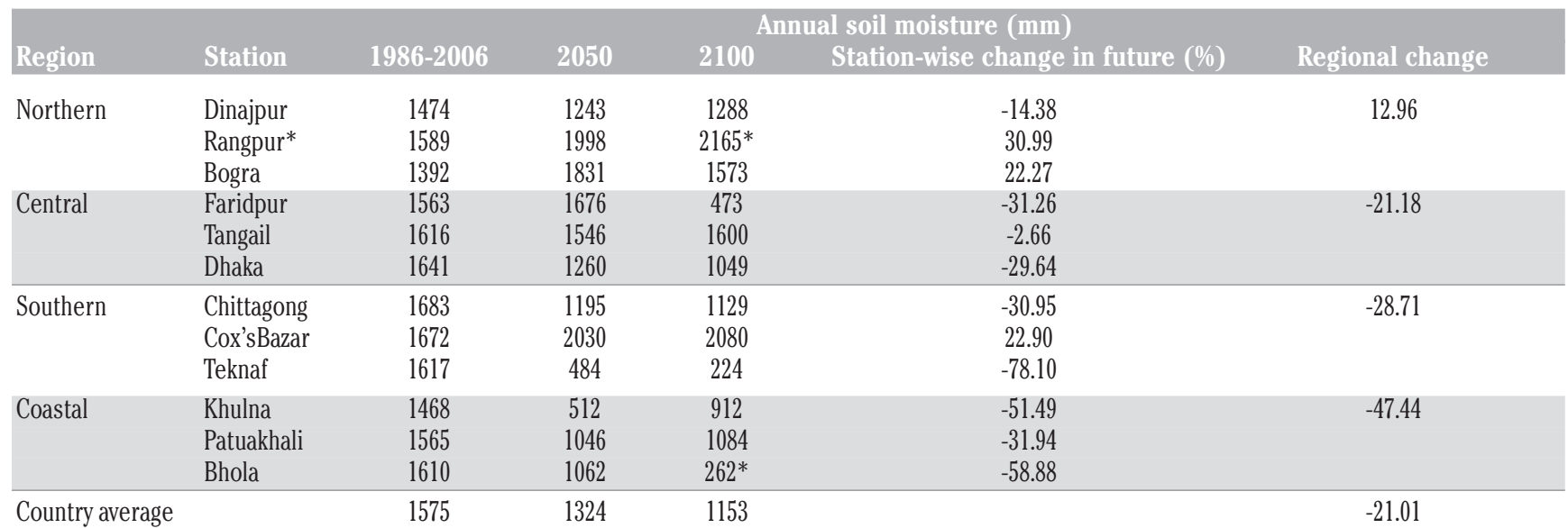

*Projected result for the year 2098, due to lack of climate projection data; "-" denotes reduction in soil moisture. 
soil, the PET and AET values tend to become the same, but in the dry season, the AET values became lower than the PET values for the same locations. Currently, the annual average AET is lower than the PET at all stations (Table 2), indicating a periodic shortage of water for crop cultivation.

\section{Water deficit}

When the combination of rainfall and previously stored soil moisture cannot meet the demand for evapotranspiration, a WD condition occurs. The region-based annual average WD is shown in Table 2. The northern belt had the highest average WD of $178 \mathrm{~mm} \mathrm{yr}^{-1}$ over the study period, whereas the central and southern parts had comparatively lower WD because of high rainfall (Table 2). Of all the stations, Bogra showed the highest average maximum WD of $202 \mathrm{~mm} \mathrm{yr}^{-1}$ and Dinajpur showed the second highest value of $190 \mathrm{~mm} \mathrm{yr}^{-1}$, while Dhaka showed the lowest WD of $128 \mathrm{~mm} \mathrm{yr}^{-1}$ (Table 2). In general, WD was the most pronounced during the winter cropping season in all the studied regions (Figure 6), while summer cropping faced moderate water shortage. During the monsoon season, the highest WD was noted in the coastal belt, $2.5 \mathrm{~mm} \mathrm{month}^{-1}$ (Figure 6). Following the summer,

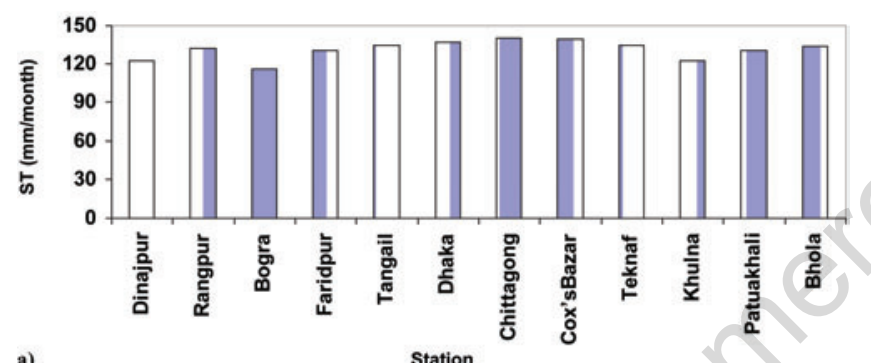

a)

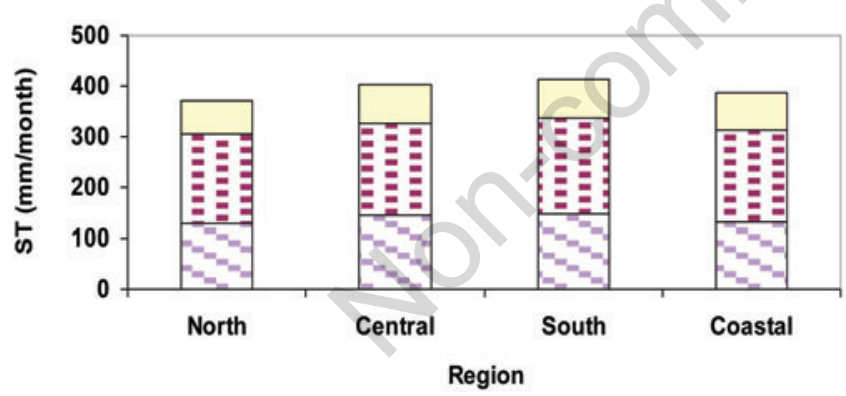

b) $\square$ Summer $\square$ Monsoon $\square$ Winter

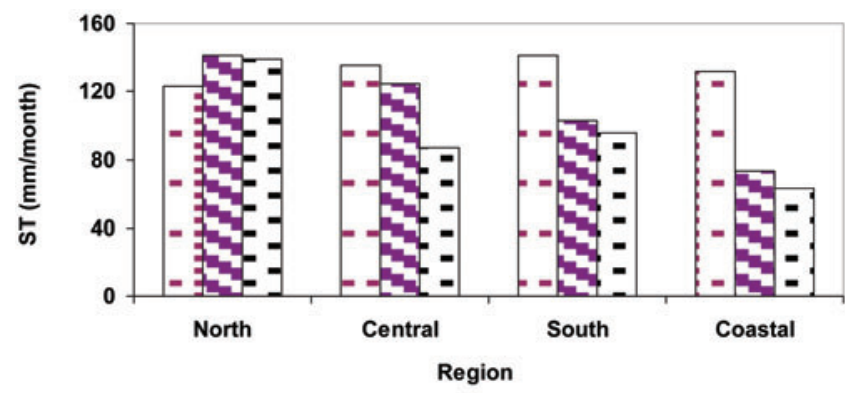

c)

$\square$ Current $\square 2050 \square 2100$

Figure 4. a) Station-wise monthly average soil moisture; b) regionwise seasonal soil moisture; c) regional current and projected soil moisture. northern Bangladesh had the maximum WD of $28 \mathrm{~mm} \mathrm{month}^{-1}$ during the winter period (Figure 6). WD needs to be treated by supplementary irrigation at the appropriate time to ensure the highest crop yield. Amin et al. (2004) showed that November to March and some days in April are periods of deficit in Bangladesh, since rainfall is less than the PET; this supports the analysis of the present study. Talukder et al. (1994) stated that when rainfall is less than evaporation, the soil moisture is utilized and a WD condition occurs. The distribution of WD provides a basic estimate of the water to be supplied by irrigation at different times and locations. Northern stations such as Dinajpur and Bogra had higher WD, while Dhaka and Tangail in the central region had relatively lower WD. During winter, Chittagong and Khulna had lower WD owing to high rainfall and the low atmospheric loss of water. The regional annual average water shortage (Table 2) indicated high water scarcity in the northern belt $(15 \mathrm{~mm} / \mathrm{month})$. High water stress during the maturing, flowering, and flowering and maturing stages resulted in rice yield decreases of $37 \%, 46 \%$, and $73 \%$, respectively, for the transplanting date $1^{\text {st }}$ June, while the losses were $39 \%, 57 \%$, and $70 \%$, respectively, for the transplanting date $15^{\text {st }}$ July (Mahmood et al., 2004). Jensen et al. (1993) used a daily water balance simulation technique for a cropping system of rain-fed pre-monsoon rice (aus) followed by monsoon rice (aman) to show that the probable irrigation requirement during the reproductive period increased from $0 \mathrm{~mm}$ in the northeast to $225 \mathrm{~mm}$ in northwest Bangladesh; however, they neglected seepage and distribution losses that also supported the results obtained for northern Bangladesh. Monsoon rice was low-yielding owing to water stress in the tillering stage; however, the reproductive stage was supported by sufficient rainfall in August. This crop suffered from moisture stress when the rainfall ceased in October for some of the years studied, showing the importance of the soil moisture reserve.

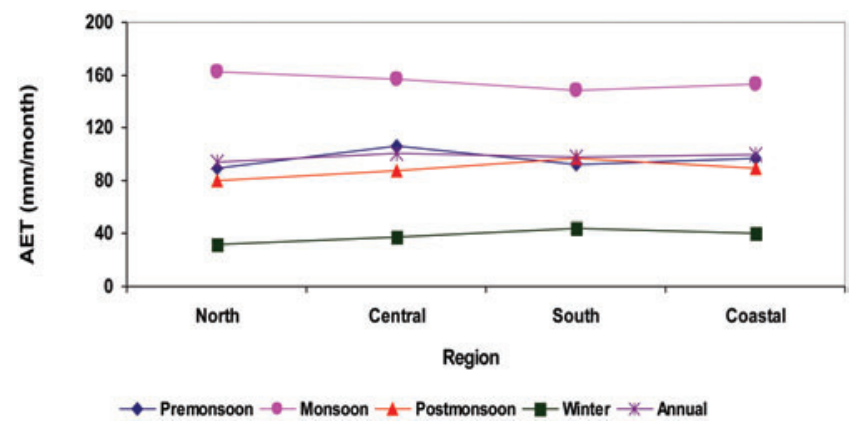

Figure 5. Region-wise seasonal actual evapotranspiration.

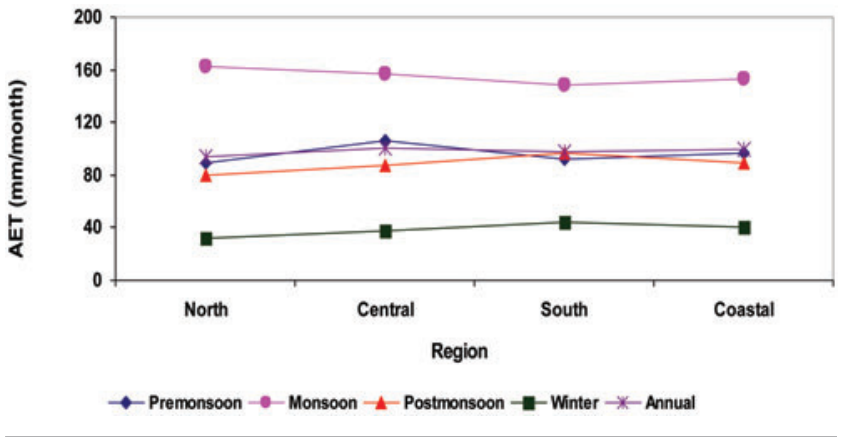

Figure 6. Region-wise seasonal water deficit. 


\section{Water surplus}

After heavy rainfall, when the demand of PET was met and the soil was replenished by the required amount of water, the excess water from rainfall was obtained as surplus (WS). This water became a source of surface runoff and drained to the nearest stream; however, a part of the WS went underground through seepage, percolation, leaching, etc. In Bangladesh, June, July, and August comprise the core rainy period that brings heavy torrential rainfall, causing a huge WS. From May to October, rainfall exceeded the PET and the depleted soil moisture was recharged until May. However, from June onward, a huge amount of WS was found in most of the studied regions, which indicated favorable conditions for monsoon cropping. About four-fifths of the mean annual rainfall occurred during these months, and no agricultural problems were generally observed, except for flooding in some cases. The highest mean annual WS (2962 mm) was observed at Teknaf, while the minimum value of $535 \mathrm{~mm} \mathrm{yr}^{-1}$ was noted for Khulna (Table 2). Dinajpur and Rangpur, situated in the northwestern part of the country, had a WS of about 75 and $92 \mathrm{~mm} \mathrm{month}^{-1}$, respectively, while the southern stations of Cox's Bazar and Teknaf showed an average WS of 202 and $246 \mathrm{~mm} \mathrm{month}^{-1}$, respectively (Figure 7).

\section{Statistical analysis for rice production and moisture}

The observed significant positive relationship $(\mathrm{P}<0.05)$ between the rice yields and the annual average soil moisture in the northern station of Dinajpur (Figure 8) indicated that optimum soil moisture and other

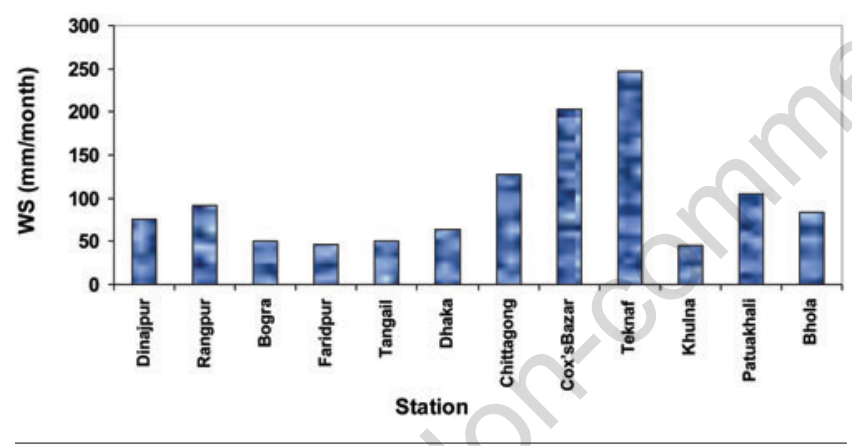

Figure 7. Station-wise average monthly water surplus.

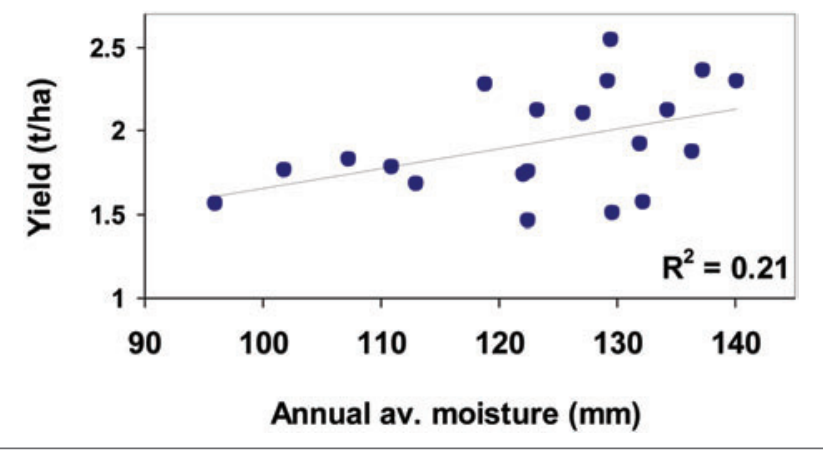

Figure 8. Soil moisture effects on annual average rice yields in Dinajpur. production inputs were the reasons for the increased yields during the period 1986 to 2006. The relationship between the available soil moisture and the current rice production in other districts also showed a positive relationship in most cases, indicating that the current high soil moisture favored rice production in Bangladesh.

\section{Conclusions}

Using the Thornthwaite water balance model, the major water balance components were calculated for 12 rice growing stations of Bangladesh. Hindcast climate data were collected from the Bangladesh Meteorological Department, while the projections were based on the IPCC 2007 climate change projection report. Currently, the northern part of Bangladesh is the area worst affected by water scarcity, and in all the studied stations, winter is the most critical season influencing water scarcity. PET was the highest in the coastal parts and decreased toward the northern belt. In the stations of Khulna and Patuakhali, the average monthly PET was 113 and $111 \mathrm{~mm}$, respectively; Rangpur had the lowest value of $107 \mathrm{~mm}$ month $^{-1}$. The average monthly AET was higher in the central stations and decreased toward the northern parts. WD was the lowest for Dhaka (128 $\left.\mathrm{mm} \mathrm{yr}^{-1}\right)$ and the highest for Bogra (202 mm $\mathrm{yr}^{-1}$ ), indicating that the northern part of Bangladesh required more irrigation than did the central and southern parts. During the monsoon, WS was noted in all the studied stations, indicating that this season is the most suitable for the cultivation of a wide variety of crops in drought-prone areas. Projection results showed that almost all the studied stations in Bangladesh would suffer from low soil moisture, which might result in a high percentage of crop loss. However, a $13 \%$ increase in projected soil moisture for the northern region of Bangladesh, showed the less demand of irrigation water there in future. The soil moisture is expected to decrease by $21 \%$ on average in all regions in Bangladesh.

Most parts of Bangladesh suffered from WD in the months November to April, indicating that irrigation must be started in the later months of the year and continued till the early months of the next year. Since a homogeneous climatic pattern exists in all parts of Bangladesh, major crops such as rice, wheat, maize, and potato can be grown easily in all seasons, but only on the condition that irrigation is provided whenever necessary. To cope with the adverse consequences of climate change, integrated adaptation and mitigation measures must be taken for agriculture, for example, efficient water use, introduction of droughtresistant varieties, and alteration of cropping practices. A significant positive relationship $(\mathrm{P}<0.05)$ between the soil moisture and the current rice yields in the northern stations showed that conservation of surplus water is essential for the future, especially in the droughtprone zone of Bangladesh.

\section{References}

Agrawala S, Ota T, Ahmed AU, Smith J, van Aalst M, 2003. Development and climate change in Bangladesh: focus on coastal flooding and the sundarbans. Organization for Economic Co-operation and Development (OECD), Paris, France.

Ahmed AR, Bhuiya AA, Reza ZA, Hossain Z, 2004. Methods of Statistics. 1st ed., S. Ahmed \& Associates, Dhaka, Bangladesh, pp 193-230.

Amin MGM, Ali MH, Islam AKMR, 2004. Agro-climatic analysis for crop planning in Bangladesh. Bangladesh J. Agri. Engg. 15:31-40.

Armstrong AM, 1996. Relief and development: some observations from the RDRS-ODA drought response project. Grassroots 8:43-53.

Bangladesh Agricultural Research Council, 1990. Drought in 
Bangladesh agriculture and irrigation schedule in major crops. pp. 15.

Bangladesh Bureau of Statistics, 2007, 2009. Handbook of Agricultural Statistics. Stat. Div. Ministry of Planning. Government of People's Republic of Bangladesh Publ., Dhaka, Bangladesh.

Bangladesh Bureau of Statistics, 1972-2007. Statistical Year Book of Bangladesh. Stat. Div. Ministry of Planning. Government of People's Republic of Bangladesh Publ., Dhaka, Bangladesh.

Eitzinger J, Tastna MS, Alud ZZ, Dubrovsky M, 2003. A simulation study of the effect of soil water balance and water stress on winter wheat production under different climate change scenarios. Agr. Water Manage. 61:195-217.

Ghan SJ, 1992. The GCM credibility gap. Clim. Change 21:345-346.

Hamon WR, 1961. Estimating potential evapotranspiration. Proc. Am. Soc. Civil Engineers 87:107-120.

Islam MD, Mondal MK, 1992. Water management strategy for increasing monsoon rice production in Bangladesh. Agr. Water Manage. 22:335-343.

Jensen JR, Mannan SMA, Uddin SMN, 1993. Irrigation requirement of transplanted monsoon rice in Bangladesh. Agr. Water Manage. 23:199-212.

Karim Z, Hussain SG, Ahmed AU, 1999. Climate change vulnerability of crop agriculture. In: S. Huq and M. Asaduzzaman (eds.) Vulnerability and adaptation to climate change for Bangladesh. Kluwer Academic Publ., Dordrecht, The Netherlands.

Khan MBR, Moinuddin M, Sarker PK, 1991. Some probability aspects of rainfall in Gazipur. Bangladesh J. Agr. 16:61-70.

Lal A, Singh KK, Rathore LS, Srinivasan G, Saseendran SA, 1998. Vulnerability of rice and wheat yields in NW India to future changes in climate. Agr. Forest Meteorol. 89:101-114.

Mahmood R, Legates DR, Meo M, 2004. The role of soil water availability in potential rainfed rice productivity in Bangladesh: applications of the CERES-Rice model. Appl. Geogr. 24:139-159.

Master Planning Organization, 1991. National water management plan: Phase II, Final Report. Ministry of Irrigation, Water Development and Flood Control, Government of the People's Republic of Bangladesh Publ., Dhaka, Bangladesh.

McCabe GJ, Markstrom SL, 2007. A Monthly water-balance model driven by a graphical user interface. US Geological Survey Open-File Report 2007-1088. Available from: http://pubs.usgs.gov/of/2007/ 1088/pdf/of07-1088_508.pdf

Mitchell JFB, Manabe S, Meleshko V, Tokioka T, 1990. Equilibrium climate change and its implications for the future. In: J.L. Houghton, G.I. Jenkins and J.J. Ephraums (eds.) Climate Change. The IPCC Scientific Assessment. Cambridge University Press, Cambridge, UK.

Murshid KAS, 1987. Weather, new technology instability in food grain production in Bangladesh. Bangladesh Dev. Stud. 15:31-56.

Quadir DA, Hossain MA, Ahasan MN, 2004. Deficit and excess rainfall conditions over Bangladesh. pp 25-32 in Proc. SAARC Seminar on Agricultural Applications of Meteorology, Dakha, Bangladesh.

Ramamasy S, Baas S, 2007. Climate variability and change: adaptation to drought in Bangladesh. A Resource Book and Training Guide. Asian Disaster Preparedness Center. FAO Publ., Roma, Italy.

Talukdar MSU, Ali MM, Hye MA, Hossain MG, 1994. Prediction of cumulative rainfall deficits using growth models. Bangladesh J. Agr. Sci. 21:377-383. 